\title{
Single-channel properties of a stretch-sensitive chloride channel in the human mast cell line HMC-1
}

\author{
Lina Wang • Guanghong Ding • Quanbao Gu • \\ Wolfgang Schwarz
}

Received: 25 July 2009/Accepted: 9 September 2009/Published online: 13 October 2009

(C) The Author(s) 2009. This article is published with open access at Springerlink.com

\begin{abstract}
A stretch-activated (SA) $\mathrm{Cl}^{-}$channel in the plasma membrane of the human mast cell line HMC-1 was identified in outside-out patch-clamp experiments. SA currents, induced by pressure applied to the pipette, exhibited voltage dependence with strong outward rectification $(55.1 \mathrm{pS}$ at $+100 \mathrm{mV}$ and an about tenfold lower conductance at $-100 \mathrm{mV}$ ). The probability of the SA channel being open $\left(P_{\mathrm{o}}\right)$ also showed steep outward rectification and pressure dependence. The open-time distribution was fitted with three components with time constants of $\tau_{1 \mathrm{o}}=755.1 \mathrm{~ms}, \tau_{2 \mathrm{o}}=166.4 \mathrm{~ms}$, and $\tau_{3 \mathrm{o}}=16.5 \mathrm{~ms}$ at $+60 \mathrm{mV}$. The closed-time distribution also required three components with time constants of $\tau_{1 \mathrm{c}}=661.6 \mathrm{~ms}$, $\tau_{2 \mathrm{c}}=253.2 \mathrm{~ms}$, and $\tau_{3 \mathrm{c}}=5.6 \mathrm{~ms}$ at $+60 \mathrm{mV}$. Lowering extracellular $\mathrm{Cl}^{-}$concentration reduced the conductance, shifted the reversal potential toward chloride reversal potential, and decreased the $P_{\mathrm{o}}$ at positive potentials. The $\mathrm{SA} \mathrm{Cl}^{-}$currents were reversibly blocked by the chloride channel blocker 4,4'-diisothiocyanatostilbene-2,2'-disulfonic acid (DIDS) but not by (Z)-1-( $p$-dimethylaminoethoxyphenyl)-1,2-diphenyl-1-butene (tamoxifen). Furthermore, in HMC-1 cells swelling due to osmotic stress, DIDS could inhibit the increase in intracellular $\left[\mathrm{Ca}^{2+}\right]$ and degranulation. We conclude that in the HMC-1
\end{abstract}

L. Wang · G. Ding · Q. Gu · W. Schwarz ( $)$

Shanghai Research Center for Acupuncture and Meridians, Department of Mechanics and Engineering Science, Fudan University, 220 Handan Rd, Shanghai 200433, China

e-mail: wolfgang.schwarz@mpibp-frankfurt.mpg.de

G. Ding

e-mail: ghding@fudan.edu.cn

L. Wang · W. Schwarz

Max Planck Institute for Biophysics, Max-von-Laue Str. 3, 60438 Frankfurt am Main, Germany cell line, the SA outward currents are mediated by $\mathrm{Cl}^{-}$ influx. The $\mathrm{SA} \mathrm{Cl}^{-}$channel might contribute to mast cell degranulation caused by mechanical stimuli or accelerate membrane fusion during the degranulation process.

Keywords HMC-1 - Mast cell degranulation . Stretch-activated $\cdot$ Chloride channel $\cdot$ DIDS

\section{Introduction}

Mast cells (MCs) are ubiquitous in the body, especially in connective tissue and mucous membranes. They play a significant role in the pathophysiology of many diseases including asthma and allergies, pulmonary fibrosis, and rheumatoid arthritis (Bradding and Holgate 1999). In addition to these deleterious activities, MCs are involved in protection from inflammation and help to maintain tissue homeostasis (Yong 1997). These pathophysiological and physiological effects are mediated through release of preformed (granule-derived) mediators and newly generated autacoids and cytokines in response to various stimuli (Caulfield et al. 1980). Ion movement across the lipid membrane mediated by membrane proteins initiates the mediator release (Bradding and Conley 2002). $\mathrm{Cl}^{-}$channels are the dominating anion channels on MCs. They are active at rest or activated by calcium ionophores (Duffy et al. 2001a, b), external agonists and internal messengers (Dietrich and Lindau 1994; Duffy et al. 2001a; Friis et al. 1994; Matthews et al. 1989; Meyer et al. 1996; Penner et al. 1988; Romanin et al. 1991), and hypotonicity (Duffy et al. 2001b). $\mathrm{Cl}^{-}$channels on MCs are involved in cellular proliferation (Duffy et al. 2001a, 2003), maintaining membrane potential at rest together with $\mathrm{K}^{+}$channels (Hill et al. 1996; Kuno et al. 1995), and in degranulation 
(Dietrich and Lindau 1994; Friis et al. 1994). In addition, $\mathrm{Cl}^{-} / \mathrm{HCO}_{3}{ }^{-}$exchangers existing in rat peritoneal mast cells (RPMCs) determine steady-state $\mathrm{pH}_{\mathrm{i}}$ (Jensen et al. 1998), and cystic fibrosis transmembrane conductance regulator (CFTR) channels expressed in rat MCs are believed to be related to mediator release (Kulka et al. 2002).

Mechanics is an effective stimulus to active MCs (Noli and Miolo 2001), but only a few studies have been performed on it. The human mast cell line HMC-1, originating from a patient with mast cell leukemia and expressing several features of mature human mast cells, provides a valuable model for studying human mast cell biology (Butterfield et al. 1988). It is reported that $75 \%$ of normal external osmolarity can induce an outwardly rectifying conductance typical of CLC-3 in HMC-1 (Duffy et al. 2001b). But detailed information about this mechanosensitive chloride channel expressed in HMC-1 is lacking. In this study, we used outside-out patch clamp electrophysiological recordings to identify mechanosensitive $\mathrm{Cl}^{-}$currents. The aim of this study is to contribute to an understanding of the relation between the mechanical stimulus and the activation or degranulation of MCs.

\section{Materials and methods}

\section{Cell culture}

Human mast cells HMC-1 (kindly provided by Dr. J. H. Butterfield, Mayo Clinic, Rochester, MN, USA) were cultured in IMDM (Gibco, Invitrogen, Grand Island, NY, USA), supplemented with $2 \mathrm{mM}$ L-glutamine, $25 \mathrm{mM}$ HEPES, $10 \%$ (v/v) fetal bovine serum (Gibco, Invitrogen, Australia), and $1 \%$ penicillin and streptomycin (Gibco, Invitrogen, Grand Island, NY, USA), in a $95 \%$ humiditycontrolled incubator with $5 \% \mathrm{CO}_{2}$ at $37^{\circ} \mathrm{C}$.

Solutions and reagents

In electrophysiological experiments, standard extracellular bath solution for outside-out configuration contained the following (in mM): $150 \mathrm{NaCl}, 5 \mathrm{KCl}, 2 \mathrm{CaCl}_{2}, 5 \mathrm{MgCl}_{2}$, 4 D-sorbitol, and 10 HEPES, pH 7.4 (adjusted with $\mathrm{NaOH}$ ). In low $\left[\mathrm{Cl}^{-}\right.$] media, $\mathrm{NaCl}$ was substituted by $\mathrm{Na}$-gluconate. $\mathrm{Cl}^{-}$-free solution was prepared by replacement of all chloride salts with the corresponding gluconate salts. The pipette solution was composed of the following (in $\mathrm{mM}$ ): $140 \mathrm{CsCl}, 1 \mathrm{CaCl}_{2}, 2 \mathrm{MgCl}_{2}, 5$ EGTA, 15 HEPES, pH 7.2 (adjusted with Tris). Osmolarity was $310 \mathrm{mOsm} / \mathrm{kg} \mathrm{H}_{2} \mathrm{O}$. For osmotic stress experiments, hypotonic solution (230 $\mathrm{mOsm} / \mathrm{kg} \mathrm{H}_{2} \mathrm{O}$ ) was prepared from the following (in $\mathrm{mM}$ ): $110 \mathrm{NaCl}, 5 \mathrm{KCl}, 2 \mathrm{CaCl}_{2}, 5 \mathrm{MgCl}_{2}, 10 \mathrm{HEPES}, \mathrm{pH}$ 7.4 (adjusted with $\mathrm{NaOH}$ ). Osmolarity was adjusted to 250 or $310 \mathrm{mOsm} / \mathrm{kg} \mathrm{H}_{2} \mathrm{O}$ by adding D-sorbitol. The osmolarity of all solutions was regularly measured by vapor pressure osmometer (Wescor Model 5520, Logan, UT).

Stock solutions of 4,4'-diisothiocyanatostilbene$2,2^{\prime}$-disulfonic acid (DIDS) (Sigma) (200 mM), (Z)-1-(p-dimethylaminoethoxyphenyl)-1,2-diphenyl-1-butene (tamoxifen) (Sigma) (100 mM), and cytochalasin B (Sigma) (20 mM) were prepared with DMSO. Calcium Green-1 AM was dissolved in 20\% (w/v) Pluronic F-127 (Invitrogen, USA) to $50 \mathrm{mM}$ stock solution. Probenecid (Sigma) was prepared in $1 \mathrm{M} \mathrm{NaOH}$ to $250 \mathrm{mM}$ stock solution. All stock solutions were stored at $-20^{\circ} \mathrm{C}$ and diluted into bath solution to working concentrations when used. DMSO was kept at less than $1 \%$ in all test solutions.

\section{Electrophysiological recordings}

Outside-out patch voltage-clamp recording was performed (if not stated otherwise) with EPC-10 amplifier using Pulse software (in initial experiments) or PatchMaster software (HEKA Electronics, Lambrecht, Germany) at room temperature $\left(25-26^{\circ} \mathrm{C}\right)$. The outside-out conformation allowed fast solution changes at the external membrane surface. Patch pipette electrodes had resistances of 3-6 M $\Omega$. The $\mathrm{Ag}-\mathrm{AgCl}$ reference electrode was connected to the bath via a $150-\mathrm{mM} \mathrm{KCl}$ agar bridge. Access resistance was monitored continuously. Single-channel events were recorded after the seal resistance had approached 2-5 G $\Omega$. Membrane potentials were clamped at $0 \mathrm{mV}$, and voltage pulses of 5-s duration were applied from -100 to $+100 \mathrm{mV}$ in $20-\mathrm{mV}$ increments. Data were sampled at $10 \mathrm{kHz}$ and filtered at $1,0.5$, or $0.1 \mathrm{kHz}$. Membrane tension was changed by applying suction to or blowing into the patch pipette using a micrometer-driven syringe; final pressure was reached within $4 \mathrm{~s}$. Pressure was monitored with a manometer (Model 8205, PCE Group, Meschede, Germany).

Light and fluorescence images

In order to observe the effects of osmotic stress on degranulation of HMC-1, inverted light microscope (TE2000-U, Nikon, Japan) and CCD video camera (OrcaER, Hamamatsu, Japan) were used. Photos were taken every 5 min during an experiment at magnification of $400 \times$.

For fluorescence experiments, HMC-1 cells grown on glass coverslips coated with poly-L-lysine (Sigma Chemical) for $10 \mathrm{~min}$ were loaded with $4 \mu \mathrm{M}$ Calcium Green-1 AM in IMDM loading buffer for $30 \mathrm{~min}$, and then washed with standard bath solution thrice. All solutions used in fluorescence experiments contained $0.1 \mathrm{mM}$ Probenecid. A $100 \mathrm{~W}$ super high pressure mercury lamp (Nikon, 
C-SHG1) was used as light source. Excitation light was passed through an interference filter (465-495 nm) and reflected by a dichroic mirror (cut-off wave lengths $505 \mathrm{~nm}$ ) through a $40 \times$ plan objective. Filter and dichroic mirrors were from Nikon. Photos were taken every minute.

Images were digitized and averaged (five frames), background-corrected and analyzed by an image-processing system (Wasabi, Hamamatsu, Japan). Fluorescence intensities of individual cells in the field of view were determined by averaging the image intensity collected from regions of interest within each cell. All experiments were preformed at room temperature.

Statistical analysis and curve fit

Data were analyzed by using TAC software (Bruxton, Seattle, WA). ORIGIN 7.1 or 8.0 software package (OriginLab, Northampton, MA) was used for final data display. Data are expressed as means \pm SEM. Differences between samples means were determined using paired $t$-test. A $P$ value $<0.05$ was considered statistically significant. The voltage-dependence of open state probability $P_{\mathrm{o}}-V$ curves was described by least-squares fit of the Fermi equation

$P_{\mathrm{o}}(V)=P_{\mathrm{o}}^{+\infty}+\frac{P_{\mathrm{o}}^{-\infty}-P_{\mathrm{o}}^{+\infty}}{1+e^{z F\left(V-V_{1 / 2}\right) / R T}}$

where $P_{\mathrm{o}}^{+\infty}$ is the probability of $V \rightarrow+\infty, P_{\mathrm{o}}^{-\infty}$ is the probability of $V \rightarrow-\infty, z$ is the effective valency, and $R$, $T$, and $F$ have their usual meaning. The values for the parameters given in the text were obtained by fitting Eq. 1 to each experiment, and then the average values were calculated. The potential range for $P_{\mathrm{o}}-V$ curves under stretch conditions was from -100 to $+60 \mathrm{mV}$.

\section{Results}

\section{SA currents of HMC-1}

At rest, most excised patches were quiescent, but in 8 out of 76 patches single-channel activity could be detected. The active currents showed outward rectification (Fig. 1) with a chord conductance of $56.2 \pm 10.9 \mathrm{pS}$ at $+100 \mathrm{mV}$ and a reversal potential of $-7.1 \pm 5.3 \mathrm{mV}$. The probability of the channels being open $\left(P_{\mathrm{o}}\right)$ was $0.05 \pm 0.01$ at $+60 \mathrm{mV}$. The currents were dependent on extracellular chloride concentration $\left(\left[\mathrm{Cl}^{-}\right]_{\mathrm{o}}\right.$ ) (Fig. 1a) and sensitive to $200 \mu \mathrm{M}$ DIDS, which is an effective $\mathrm{Cl}^{-}$channel blocker (Duan et al. 1997b; Matthews et al. 1989; Miller and White 1984) (Fig. 1b). Occurrence of the currents could be due to spontaneous activity or to residual membrane tension produced by the formation of outside-out mode.

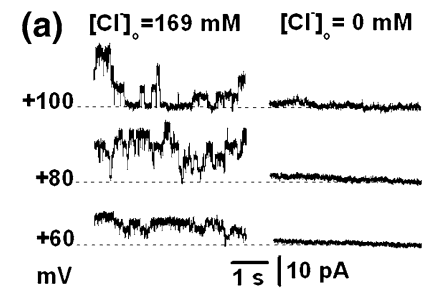

(b) Control $200 \mu \mathrm{M}$ DIDS

Fig. 1a, b Properties of spontaneous single-channel currents recorded in outside-out configuration from HMC-1. a Representative current traces at various potentials in the presence and absence of physiological $(169 \mathrm{mM})$ external $\mathrm{Cl}^{-}$. b Representative current traces at various potentials in the presence and absence of $200 \mu \mathrm{M}$ DIDS. Data were filtered at $0.1 \mathrm{kHz}$

When mechanical stress of 30-60 $\mathrm{cm} \mathrm{H}_{2} \mathrm{O}$ was applied to excised outside-out patches via the patch pipette, singlechannel activity appeared to open more frequently with longer open times in 38 out of 72 excised patches; the single-channel amplitude did not change significantly. The SA channel currents exhibited voltage-dependence with strong outward rectification (Fig. 2b). At positive potentials, a chord conductance of about $55.1 \pm 3.4 \mathrm{pS}$ at $+100 \mathrm{mV}$ was observed as the dominating state (Fig. 2a, b) and only $4.5 \pm 1.0 \mathrm{pS}$ at $-100 \mathrm{mV}$ and a reversal potential of $-7.2 \pm 2.2 \mathrm{mV}$. Hence, single-channel conductance as well as reversal potential was similar to those of the channels active at rest. $P_{\mathrm{o}}$ was also dependent on membrane potential with outward rectification (Fig. 2c). For the potential range from -100 to $+60 \mathrm{mV}$, the dependency could be described by Eq. 1 with effective valency of the gating charge $z=2.4 \pm 0.1$ and $V_{1 / 2}=$ $6.4 \pm 2.1 \mathrm{mV}$. At extreme positive potential $P_{\mathrm{o}}$ became again reduced, which might be attributed to a property common of SA channels: time-dependent decrease in $P_{\mathrm{o}}$ on exposure to a constant or repeated pipette suction (Sackin 1995). $P_{\mathrm{o}}$ of SA channels increased with rising pressure; half-maximum channel activation occurred at $-26.4 \mathrm{~cm}$ $\mathrm{H}_{2} \mathrm{O}$ (Fig. 2d). The open-time distribution required three exponential components (Fig. 2e) with time constants of 755.1, 166.4, and $16.5 \mathrm{~ms}$, respectively. The closed-time distribution (Fig. 2f) was also fitted by the sum of three exponential components with time constants of 661.6, 253.2, and $5.6 \mathrm{~ms}$, respectively. Some SA channels closed during continuous or repeated stretch, matching the common property of mechanosensitive channels, the adaptation phenomenon (Sackin 1995). Other SA channels still remained in the open state even after stretch release, but $P_{\mathrm{o}}$ declined with pressure removal, as for $\mathrm{SA} \mathrm{Cl}^{-}$channels reported in renal cortical collecting duct cell line (Schwiebert et al. 1994) (Fig. 2f). This would provide a constant and sufficient electric driving force for cation entry (Duffy et al. 2001b; Matthews et al. 1989).

It is interesting that at pressure gradients up to $-90 \mathrm{~cm}$ $\mathrm{H}_{2} \mathrm{O}$ SA currents were hardly observed in the cell-attached 
Fig. 2a-h Single-channel properties of SA currents from HMC-1. a Representative current traces at various potentials recorded under control conditions and during $-60 \mathrm{~cm} \mathrm{H}_{2} \mathrm{O}$ application to the patch pipette. Data were filtered at $1 \mathrm{kHz}$. b Averaged currentvoltage relationships during stretch application (mean values \pm SEM, $n=38$ ). c Voltage-dependence of open probability $\left(P_{\mathrm{o}}\right)$ of SA channels $(n=38)$. The solid line represents a fit of Eq. 1 to the data in the potential range from -100 to $+60 \mathrm{mV}$; fit parameters are given in the text. d Pressure-dependence of SA channel $P_{\mathrm{o}}$. The graph shows the relationship between normalized $P_{\mathrm{o}}$ of the SA channels and negative pressure $(n=7-16)$ at $+20 \mathrm{mV}$. Data points are fitted by Eq. 1 . e Open dwell-time distributions of the SA channels at $+60 \mathrm{mV}$. Superimposed are fitted probability density functions for each component (dotted lines) and their sum (solid line). A total of 2,060 events were evaluated. The fitted time constants are given in the text. f Closed dwell-time distributions of the SA channels at $+60 \mathrm{mV}$. A total of 1,772 events were evaluated. The fitted time constants are given in the text. g Current traces recorded at $+100 \mathrm{mV}$ at different times during and after stretch application (see times listed on the right). Upward deflections represent open state. Data were filtered at $1 \mathrm{kHz}$. h Representative single-channel patch clamp recording in cellattached mode from HMC-1 pretreated with $10 \mu \mathrm{M}$ cytochalasin $\mathrm{B}$ for $12 \mathrm{~h}$ under control conditions and during $-45 \mathrm{~cm} \mathrm{H}_{2} \mathrm{O}$ application. Data were filtered at $1 \mathrm{kHz}$

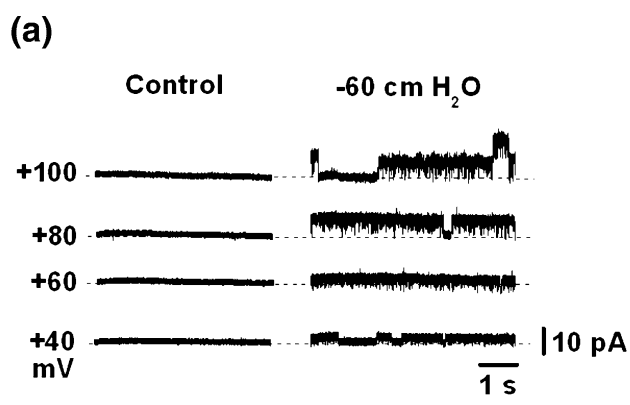

(c)

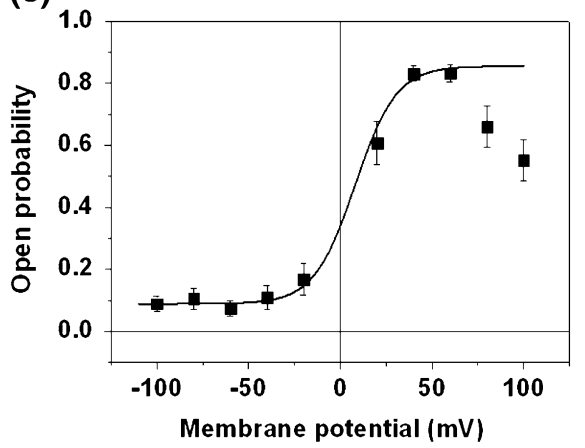

(e) Number

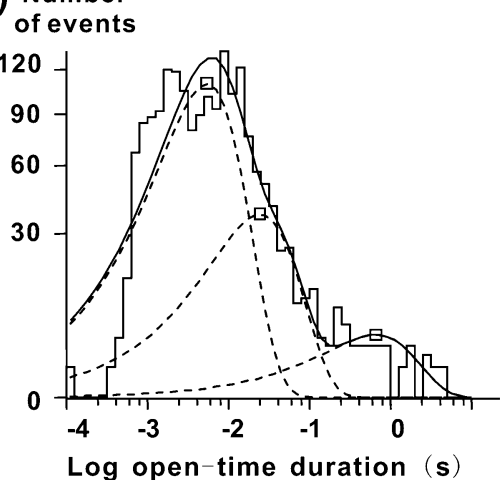

(g)

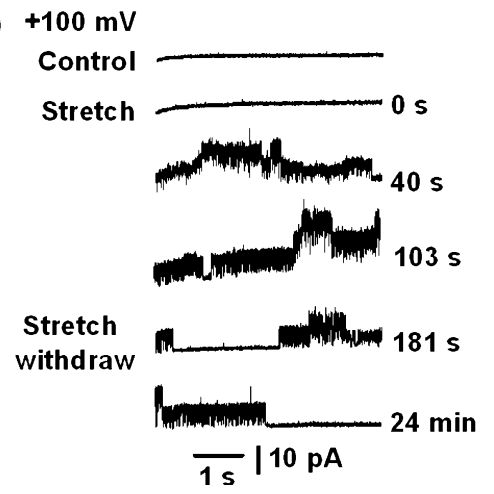

(b)

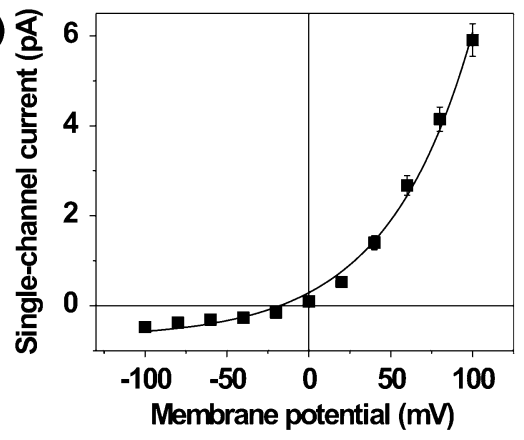

(d)

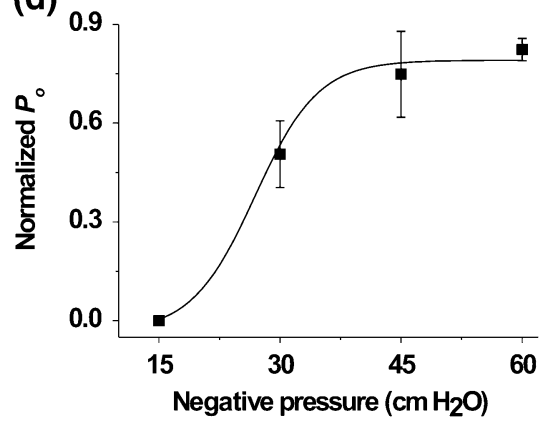

(f) Number

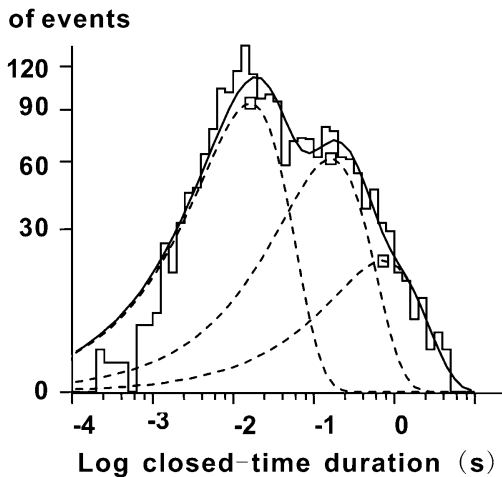

(h)

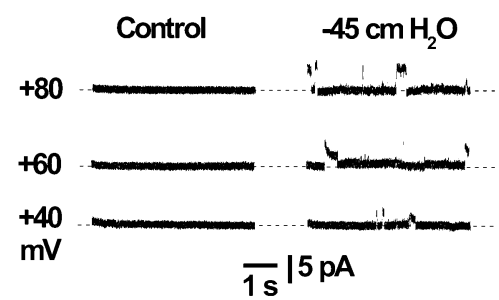

mode $(n=15)$. We presumed the cytoskeleton might counteract the activation of SA channels. So cytochalasin B was used to disrupt microfilaments (Cooper 1987; Schwiebert et al. 1994). SA currents appeared in cell-attached mode pretreated with $10 \mu \mathrm{M}$ cytochalasin $\mathrm{B}$ for $12 \mathrm{~h}$ $(n=6)$. Figure $2 \mathrm{~h}$ shows the representative recording from HMC-1 pretreated with cytochalasin B.
Response of SA currents to $\left[\mathrm{Cl}^{-}\right]_{\mathrm{o}}$

The ionic selectivity of this SA current was estimated by changing $\left[\mathrm{Cl}^{-}\right]_{\mathrm{o}}$. The outwardly rectifying currents (Fig. 3a, b) and $P_{\mathrm{o}}$ at positive potentials (Fig. 3c) became reduced when $\left[\mathrm{Cl}^{-}\right]_{\mathrm{o}}$ was decreased from 169 to $19 \mathrm{mM}$ $(n=9)$. In these sets of experiments, the chord 
Fig. 3a-c Response of SA currents in outside-out configuration of HMC-1 to $\left[\mathrm{Cl}^{-}\right]_{\mathrm{o}}$ decrease.

a Representative traces recorded from the same patch. SA current induced by $-60 \mathrm{~cm} \mathrm{H}_{2} \mathrm{O}$ in $\left[\mathrm{Cl}^{-}\right]_{\mathrm{o}}$ of 169,19 , and again $169 \mathrm{mM}$. Data were filtered at $0.1 \mathrm{kHz}$. b Mean $I-V$ curves of SA currents with

$\left[\mathrm{Cl}^{-}\right]_{\mathrm{o}}=169 \mathrm{mM}$ (filled squares) and $\left[\mathrm{Cl}^{-}\right]_{\mathrm{o}}=19 \mathrm{mM}$ (open triangles) $(n=9)$. c Mean $P_{\mathrm{o}}-V$ plots of SA currents with $\left[\mathrm{Cl}^{-}\right]_{\mathrm{o}}=169 \mathrm{mM}$ (filled squares) and $\left[\mathrm{Cl}^{-}\right]_{\mathrm{o}}=19 \mathrm{mM}$ (open triangles $)(n=9)$. Curves represent fits of Eq. 1 to the data (for $169 \mathrm{mM}$ for the potential range from -100 to $+60 \mathrm{mV}$, and for $19 \mathrm{mM}$ for the potential range from -100 to $+100 \mathrm{mV}$ ); fitted parameters are given in the text

(a)

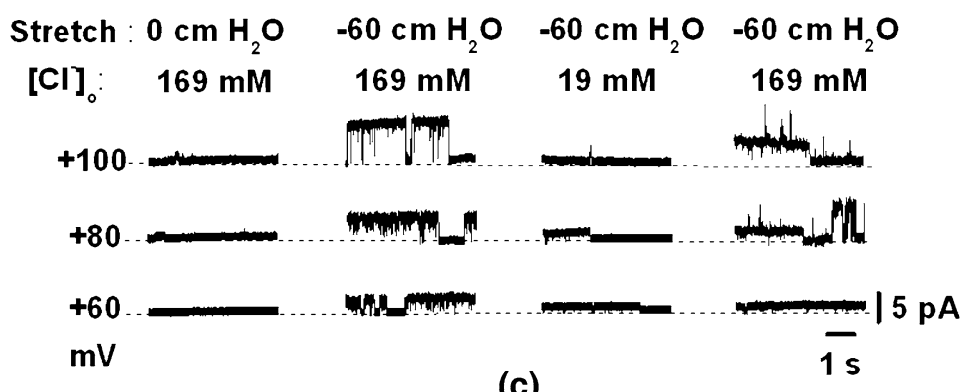

(b)

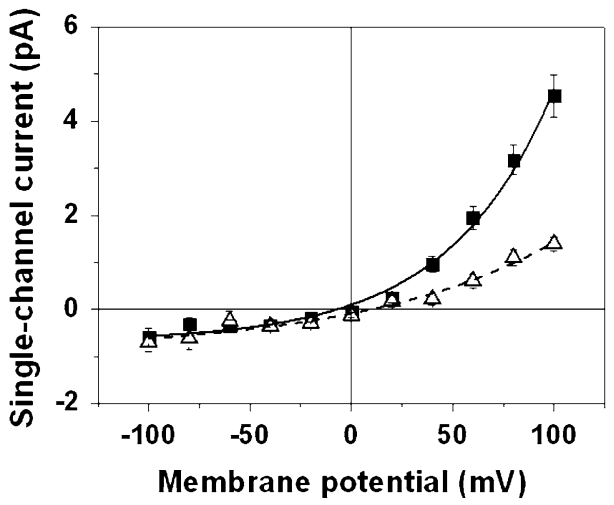

(c)

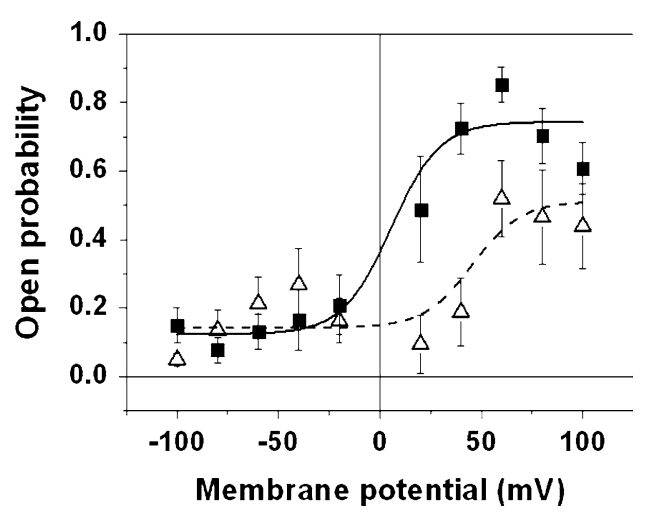

conductance at $+100 \mathrm{mV}$ decreased from $44.2 \pm 4.4$ to $15.1 \pm 1.6 \mathrm{pS}(n=9, P<0.01)$, and the reversal potential shifted from $-6.2 \pm 5.0$ to $16.2 \pm 3.7 \quad(n=9$, $P<0.01)$. Both curves of $P_{\mathrm{o}}$-potential dependence in 169 and $19 \mathrm{mM}\left[\mathrm{Cl}^{-}\right]_{\mathrm{o}}$ could be fitted by Eq. 1. Nevertheless, $P_{\mathrm{o}}$ also reduced to $62.2 \pm 13.6 \%$ of the control $(n=9$, $P<0.05)$ at $+60 \mathrm{mV}$, and the $V_{1 / 2}$ shifted from $5.5 \pm 2.7$ to $45.6 \pm 6.9 \mathrm{mV}(n=9, P<0.01)$, but effective valency $z$ did not change significantly. No single-channel events could be detected in $\mathrm{Cl}^{-}$-free solution $(n=20)$. The data are compatible with the suggestion that the SA currents are mediated by chloride movement.

Pharmacological modification of the SA channels

DIDS, known to inhibit the $\mathrm{Cl}^{-}$channel, was applied to the bath solution to test the effect on this SA channel. In the presence of $200 \mu \mathrm{M}$ DIDS, the average chord conductance decreased from $58.5 \pm 4.1$ to $18.9 \pm 7.0 \mathrm{pS}$ at $+100 \mathrm{mV}$ ( $n=9, P<0.01$ ) (Fig. 4b), and $P_{\mathrm{o}}$ at positive potentials was also reduced to $20.6 \pm 1.4 \%(n=9, P<0.01)$. The reversal potential did not change significantly. The inhibition of DIDS was reversible (Fig. 4a). Interestingly, at negative potentials, channels seemed to open more frequently in the presence of DIDS than in the absence (see Fig. $4 \mathrm{a}, \mathrm{c}$ ). The SA currents resisted tamoxifen (10 and $100 \mu \mathrm{M}, n=3$ ), another $\mathrm{Cl}^{-}$channel blocker.

Some ion channels activated by membrane stretch are also sensitive to cell swelling (Christensen and Hoffmann 1992; Schwiebert et al. 1994). Accordingly, we examined the effects of DIDS on HMC-1 incubated in hypotonic solution. The light microscopic analysis indicated that a DIDS-sensitive pathway contributes to HMC-1 degranulation. When perfused with hypotonic solution $\left(230 \mathrm{mOsm} / \mathrm{kg} \mathrm{H}_{2} \mathrm{O}\right.$ ) for up to $30 \mathrm{~min}$, degranulation of HMC-1 cells could be observed. The plasma membrane became rough and the color of cytoplasm appeared light because of degranulation (Watanabe et al. 2002). The degranulation ratio of HMC-1 in hypotonic solution was $54.9 \pm 8.5 \%$ (in four independent experiments), which could be inhibited by $200 \mu \mathrm{M}$ DIDS to $17.7 \pm 4.5 \%$ (in four independent experiments, $P<0.05$ vs. hypotonicity) (Fig. 5). Tamoxifen did also not significantly affect the degranulation. Using Calcium Green-1 $\mathrm{AM}$ as $\mathrm{Ca}^{2+}$-sensitive dye, we found that the fluorescence intensity of HMC- 1 increased to $116.7 \pm 3.6 \%$ of control $(n=52$, in five independent experiments, $P<0.01$ vs. control) with exposure to hypotonic bath solution $\left(250 \mathrm{mOsm} / \mathrm{kg} \mathrm{H}_{2} \mathrm{O}\right)$ for $10 \mathrm{~min}$, which could be inhibited by $200 \mu \mathrm{M}$ DIDS to $79.9 \pm 4.2 \%(n=29$, in four independent experiments, $P<0.01$ vs. hypotonicity) (Fig. 6). Also, $200 \mu \mathrm{M}$ DIDS partially inhibited degranulation of HMC-1 induced by pretreatment of $10 \mu \mathrm{M}$ cytochalasin $\mathrm{B}$.

\section{Discussion}

Chloride channels are ubiquitous and present in most excitable and nonexcitable cells (Jentsch et al. 2002), including MCs. In HMC-1, mRNA for CLC-5 and CLC-3 


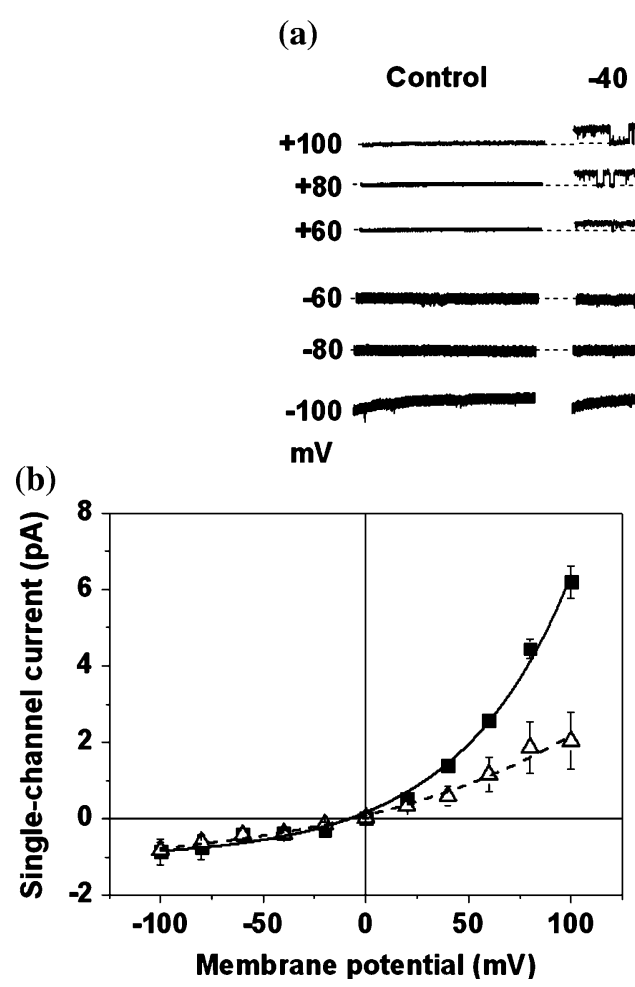

Fig. 4a-c Response of SA currents in outside-out configuration of HMC-1 to $200 \mu \mathrm{M}$ DIDS. a Current traces recorded from the same patch. SA currents were induced by $-40 \mathrm{~cm} \mathrm{H}_{2} \mathrm{O}$ applied to the patch pipette in the presence and absence of $200 \mu \mathrm{M}$ DIDS. Data were filtered at $0.1 \mathrm{kHz}$. b Mean $I-V$ curves of SA currents with (open triangles) and without (filled squares) DIDS $(n=9)$. c Mean $P_{\mathrm{o}}-V$

had been detected by RT-PCR (Duffy et al. 2001b). Wholecell patch clamp experiments revealed strong outwardly rectifying $\mathrm{Cl}^{-}$currents at rest; from cell-attached experiments, a single-channel slope conductance of $42 \mathrm{pS}$ and a reversal potential of about $-15 \mathrm{mV}$ was estimated (Duffy et al. 2001b). The authors suggested that this current was mediated by CLC-5-like channels and that they might contribute to the cell's resting potential close to $0 \mathrm{mV}$ and to the malignant phenotype of the cells. In the HMC-1, hypotonicity-activated $\mathrm{Cl}^{-}$currents were also described that were attributed to CLC-3 channels and might be involved in cell volume regulation (Duffy et al. 2001b). Besides HMC-1, other MCs also express $\mathrm{Cl}^{-}$channels, which are active at rest (Duffy et al. 2003; Hill et al. 1996; Kuno et al. 1995; Meyer et al. 1996; Roloff et al. 2001) or activated by some internal or external factors (Dietrich and Lindau 1994; Duffy et al. 2001a; Friis et al. 1994; Matthews et al. 1989; Meyer et al. 1996; Penner et al. 1988; Romanin et al. 1991).

With respect to single-channel conductance and outward rectification, the channel investigated in this study resembles the CLC-5 channel described previously (Duffy et al. 2001b). The slight discrepancy in conductance might be attributed to the fact that those data were obtained from

(c)

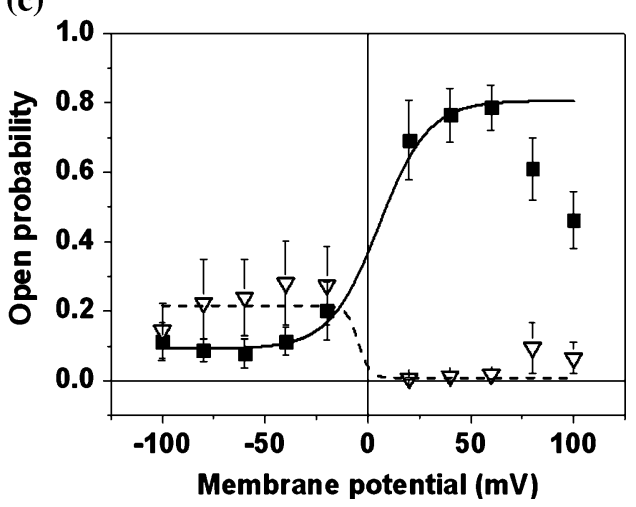

plots of SA currents with (open triangles) and without (filled squares) $200 \mu \mathrm{M}$ DIDS $(n=9)$. The solid line represents a fit of Eq. 1 to the data in the absence of DIDS for the potential range from -100 to $+60 \mathrm{mV}$; the dashed line is to indicate that channel opening was increased at negative potentials

cell-attached patches, where exact membrane potential and ionic conditions at the inner membrane surface were not exactly known. Against the involvement of CLC-5 is the fact that the single-channel currents were insensitive to tamoxifen, but sensitive to DIDS.

The channels described in our present work can also be activated by osmotic stress as has been reported for CLC-3 expressed in HMC-1 (Duffy et al. 2001b). Although stretch is a more direct mechanical stimulus than osmotic swelling, which involves several signaling pathways (Baumgarten and Clemo 2003; Poolman et al. 2002), both of them can release endogenous fatty acids that indirectly affect $P_{\mathrm{o}}$ by altering either membrane fluidity or lipid environment (Ordway et al. 1991; Schwiebert et al. 1994). Some ion channels activated by membrane stretch are also sensitive to cell swelling (Christensen and Hoffmann 1992; Schwiebert et al. 1994). Accordingly, we examined the effects of DIDS on HMC-1 incubated in hypotonic solution.

Recently, it was realized that the CLC family not only features genuine channels, but also includes $\mathrm{Cl}^{-} / \mathrm{H}^{+}$ transporters (Miller 2006; Pusch et al. 2006; Scheel et al. 2005). Human CLC-4 and CLC-5 expressed on intracellular membrane have been shown to act as $\mathrm{Cl}^{-} / \mathrm{H}^{+}$ exchangers (Pusch et al. 2006; Scheel et al. 2005). CLC-3, 
Fig. 5a-e Inhibition of DIDS on degranulation of HMC-1 caused by osmotic stress. a and b $\mathrm{HMC}-1$ cells in isotonicity (310 $\mathrm{mOsm} / \mathrm{kg} \mathrm{H} \mathrm{H}_{2} \mathrm{O}$ ) and hypotonicity $(230 \mathrm{mOsm} / \mathrm{kg}$ $\mathrm{H}_{2} \mathrm{O}$ ). c and d HMC-1 cells in isotonic solution and hypotonic solution containing $200 \mu \mathrm{M}$ DIDS. Photos in right panel were taken when HMC-1 was incubated in hypotonicity for 30 min. e Degranulation ratio of HMC-1 cells in hypotonic solution in the absence $(n=4)$ and presence of $200 \mu \mathrm{M}$ DIDS $(n=4)$
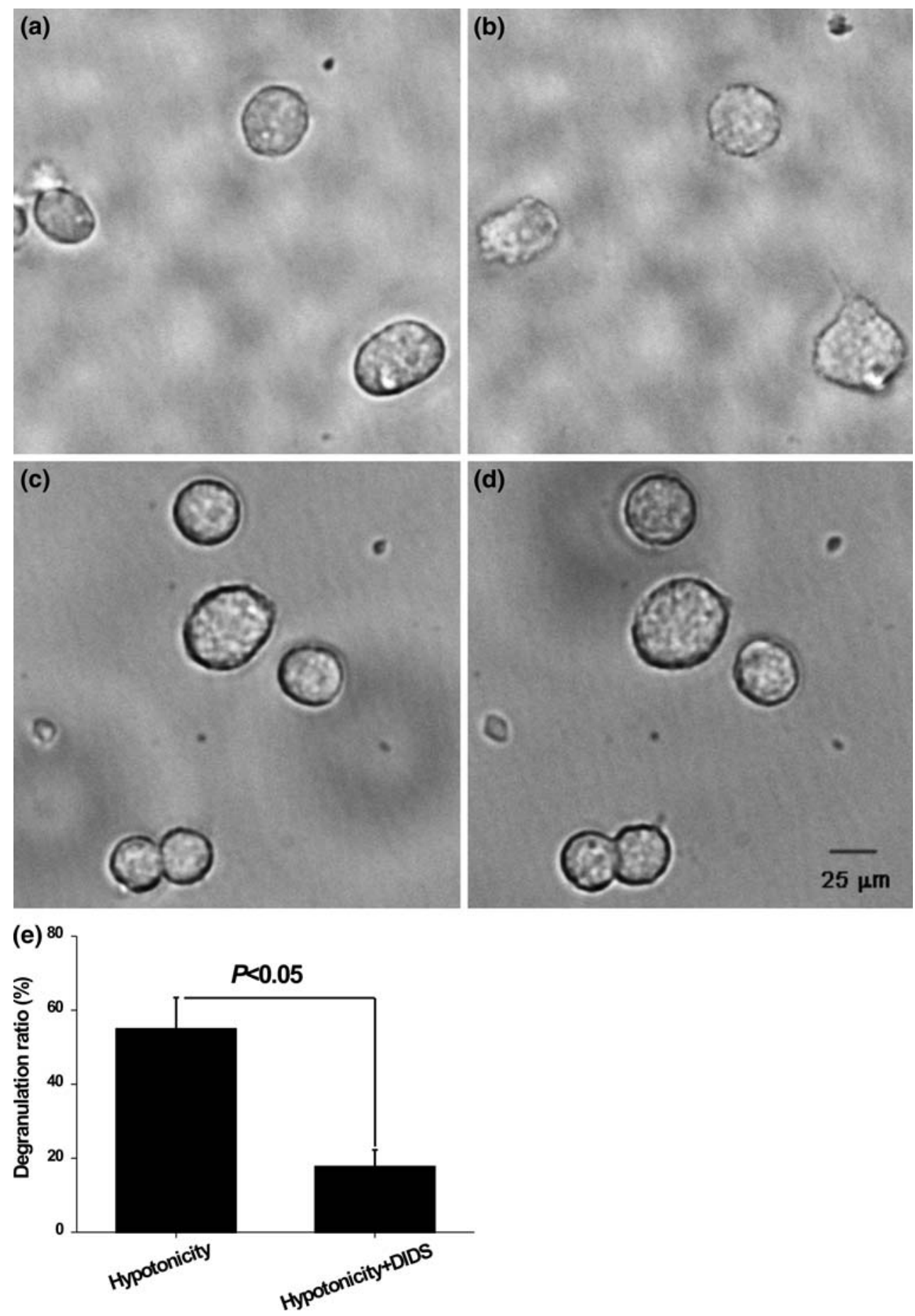

CLC-4, and CLC-5 belong to the same subbranch on the basis of sequence homology, and CLC-3 has also been reported to operate as a $\mathrm{Cl}^{-} / \mathrm{H}^{+}$transporter (Matsuda et al. 2008).

Mechano-activated $\mathrm{Cl}^{-}$channels are represented by various types of $\mathrm{Cl}^{-}$channels, and depending on the cell type, they may be activated by different mechanical mechanisms (Nilius et al. 1996). In addition, they show various conductances (Nilius et al. 1996; Sackin 1995) and have different gating properties (Duan et al. 1997a, b; Sato and Koumi 1998), pharmacology (Nilius et al. 1996), ATP dependence (Bond et al. 1999; Wu et al. 1996), and voltage dependence (outward rectification, Bond et al. 1999; Duan et al. 1997a, b; Lewis et al. 1993; Patel et al. 1998; Wu et al. 1996) or linear current-voltage curves (Sabirov et al. 2001; Sato and Koumi 1998; Schwiebert et al. 1994). Our further electrical characterization of the SA currents in HMC-1 revealed a major chord conductance of $55 \mathrm{pS}$ at 
Fig. 6a-e Changes in

fluorescence intensity of the Casensitive dye (Calcium Green-1 AM) after HMC-1 simulation by osmotic stress in the absence and presence of $200 \mu \mathrm{M}$ DIDS. $\mathbf{a}$ and $\mathbf{b}$ Fluorescent image of $\mathrm{HMC}-1$ in isotonic and hypotonic $\left(250 \mathrm{mOsm} / \mathrm{kg} \mathrm{H} \mathrm{H}_{2} \mathrm{O}\right)$ bath solutions. $\mathbf{c}$ and $\mathbf{d}$

Fluorescent image of HMC-1 in isotonicity and hypotonicity containing $200 \mu \mathrm{M}$ DIDS.

Photos in right panel were taken when HMC-1 was incubated in hypotonicity for $10 \mathrm{~min}$.

e Relative fluorescence intensity of HMC-1 during exposure to hypotonicity in the absence ( $n=52$, in five independent experiments) and presence $(n=29$, in three independent experiments) of $200 \mu \mathrm{M}$ DIDS
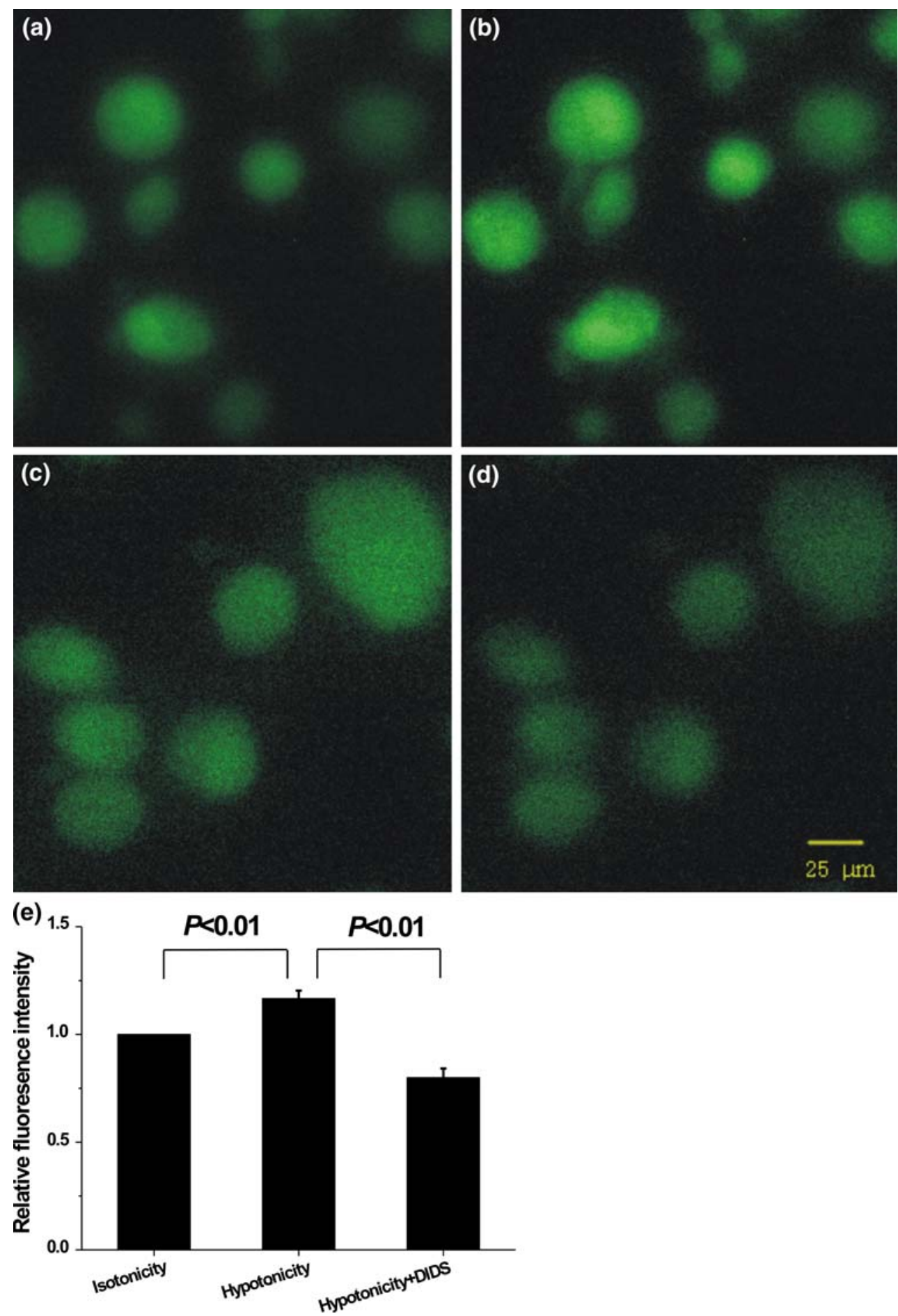

The decrease in $P_{\mathrm{o}}$ at potentials more positive than $+60 \mathrm{mV}$ has been described as an adaptation to exposure to a constant or repeated pipette suction (Sackin 1995), and it has been proposed that the mechanism of adaptation involves membrane-cytoskeleton interactions that could be decoupled by mechanical stress (Hamill and McBride 1992). 
The stilbene derivative DIDS has been shown to be an effective $\mathrm{Cl}^{-}$channel blocker, reducing $\mathrm{Cl}^{-}$currents at rest (Hill et al. 1996; Kuno et al. 1995; Meyer et al. 1996; Roloff et al. 2001) as well as $\mathrm{Cl}^{-}$currents induced by external agonists and internal messengers (Dietrich and Lindau 1994; Matthews et al. 1989; Penner et al. 1988) in the concentration range of 3-30 $\mu \mathrm{M}$. In our study we have shown that the $\mathrm{SA} \mathrm{Cl}^{-}$channels were also blocked by DIDS, but a much higher concentration of $200 \mu \mathrm{M}$ was needed. Current fluctuation analysis on RPMCs revealed that DIDS could enter and block open $\mathrm{Cl}^{-}$channels, breaking long channel openings into briefer openings and closings (Matthews et al. 1989). This would be in line with our finding that the outward currents (inward movement of $\mathrm{Cl}^{-}$) mediated by the SA channels were inhibited by DIDS with reduced $P_{\mathrm{o}}$ at positive potentials. It is interesting that $P_{\mathrm{o}}$ at negative potentials became increased by $200 \mu \mathrm{M}$ DIDS and channels with low conductance opened. Similar results were obtained in experiments with human mast cells using tamoxifen as $\mathrm{Cl}^{-}$channel blocker; tamoxifen (3$30 \mu \mathrm{M})$ produced dose-dependent block of outward currents and simultaneously opened inwardly rectifying currents recorded at rest (Duffy et al. 2003). In our work, the $\mathrm{SA} \mathrm{Cl}^{-}$currents and degranulation caused by osmotic stress were not blocked by tamoxifen, even at a concentration of $100 \mu \mathrm{M}$. This may be another indication of variable pharmacology of mechano-activated $\mathrm{Cl}^{-}$channels as we discussed before. It was reported that tamoxifen showed no inhibition to outwardly rectifying $\mathrm{Cl}^{-}$channels in guinea pig small intestinal villus enterocytes in excised outward-out configuration (Monaghan et al. 1997).

SA currents could not be detected at pressure in cellattached configuration even at pressure gradients up to $-90 \mathrm{~cm} \mathrm{H}_{2} \mathrm{O}$. Also in whole-cell configuration, higher pressure gradients $\left(>60 \mathrm{~cm} \mathrm{H}_{2} \mathrm{O}\right)$ were necessary to activate the SA currents (data not presented). We assume that the cytoskeleton and intracellular components could counteract the tension (Guharay and Sachs 1984). In outside-out mode, the disruption of actin-containing elements of the cytoskeleton and loss of intracellular components would then cause a decrease in the tension that is needed to activate SA channels compared to the whole-cell or cellattached mode. Usage of cytochalasin B in our work further proved this presumption. Degranulation is actually a process of exocytosis (Rohlich et al. 1971) during which membrane tension changes (Apodaca 2002; Hamill and Martinac 2001; Monck et al. 1990) and the cytoskeleton reorganizes (Nishida et al. 2005). We suppose SA Cl${ }^{-}$ channels might accelerate the degranulation process.

$\mathrm{Cl}^{-}$channels play vital roles in MC function-in cellular proliferation (Duffy et al. 2001a, 2003), in maintaining the resting membrane potential together with $\mathrm{K}^{+}$ channels (Hill et al. 1996; Kuno et al. 1995), and in degranulation (Dietrich and Lindau 1994; Friis et al. 1994; Kulka et al. 2002; Romanin et al. 1991). With respect to mediator release, both DIDS-sensitive (Dietrich and Lindau 1994) and DIDS-insensitive (Friis et al. 1994) $\mathrm{Cl}^{-}$ channels have been demonstrated to be involved in the process of degranulation. In our experiments, we also found that the number of degranulating cells in response to osmotic stress was reduced in the presence of DIDS. This supports the suggestion that the $\mathrm{Cl}^{-}$channels analyzed in our investigation contribute to the degranulation process. $\mathrm{Cl}^{-}$influx leads to membrane hyperpolarization, which would provide a sufficiently negative membrane potential driving $\mathrm{Ca}^{2+}$ entry (Duffy et al. 2001b; Matthews et al. 1989). An increase in $\left[\mathrm{Ca}^{2+}\right]_{i}$ can dramatically accelerate secretion in MCs (Neher 1988). In the present work, $\mathrm{Cl}^{-}$ currents could last up to nearly half an hour even after stretch release, maintaining the electrochemical driving force for $\mathrm{Ca}^{2+}$ entry.

We may ask whether mechanical stress can be a physiologically relevant stimulus. The experiments performed in our lab proved MCs in connective tissue under rat skin also have the property of stretch sensitivity (Wang et al. 2009), and previous results have showed osmotic stressinduced degranulation of these MCs could be inhibited by DIDS. We presume the mechanosensitive property of MCs, especially those dwelling in interface (skin and mucosa), may play a role in the interaction between external physics stimuli and body reaction. Furthermore, it has been demonstrated (Zhang et al. 2008) that MC degranulation contributes to initiating analgesia during acupuncture, and some physical therapy, such as cupping or massage, may also use this pathway.

Acknowledgments We are very grateful to Dr. J. H. Butterfield (Mayo Clinic, Rochester, MN, USA) for providing the HMC-1 cell line and Dr. Thomas Behnisch (Institutes of Brain Science, Fudan University, China) for guiding the fluorescent technique. This work was financially supported by the National Basic Research Program of China (973 Program, no. 2005CB523306) and Shanghai Leading Academic Discipline Project (B112, S30340 and T0302).

Open Access This article is distributed under the terms of the Creative Commons Attribution Noncommercial License which permits any noncommercial use, distribution, and reproduction in any medium, provided the original author(s) and source are credited.

\section{References}

Apodaca G (2002) Modulation of membrane traffic by mechanical stimuli. Am J Physiol Renal Physiol 282:F179-190

Baumgarten CM, Clemo HF (2003) Swelling-activated chloride channels in cardiac physiology and pathophysiology. Prog Biophys Mol Biol 82:25-42

Bond T, Basavappa S, Christensen M, Strange K (1999) ATP dependence of the ICl, swell channel varies with rate of cell 
swelling. Evidence for two modes of channel activation. J Gen Physiol 113:441-456

Bradding P, Conley EC (2002) Human mast cell ion channels. Clin Exp Allergy 32:979-983

Bradding P, Holgate ST (1999) Immunopathology and human mast cell cytokines. Crit Rev Oncol Hematol 31:119-133

Butterfield JH, Weiler D, Dewald G, Gleich GJ (1988) Establishment of an immature mast cell line from a patient with mast cell leukemia. Leuk Res 12:345-355

Caulfield JP, Lewis RA, Hein A, Austen KF (1980) Secretion in dissociated human pulmonary mast cells. Evidence for solubilization of granule contents before discharge. J Cell Biol 85:299_ 312

Christensen O, Hoffmann EK (1992) Cell swelling activates $\mathrm{K}^{+}$and $\mathrm{Cl}^{-}$channels as well as nonselective, stretch-activated cation channels in Ehrlich ascites tumor cells. J Membr Biol 129:13-36

Cooper JA (1987) Effects of cytochalasin and phalloidin on actin. J Cell Biol 105:1473-1478

Dietrich J, Lindau M (1994) Chloride channels in mast cells: block by DIDS and role in exocytosis. J Gen Physiol 104:1099-1111

Duan D, Hume JR, Nattel S (1997a) Evidence that outwardly rectifying $\mathrm{Cl}^{-}$channels underlie volume-regulated $\mathrm{Cl}^{-}$currents in heart. Circ Res 80:103-113

Duan D, Winter C, Cowley S, Hume JR, Horowitz B (1997b) Molecular identification of a volume-regulated chloride channel. Nature 390:417-421

Duffy SM, Lawley WJ, Conley EC, Bradding P (2001a) Resting and activation-dependent ion channels in human mast cells. J Immunol 167:4261-4270

Duffy SM, Leyland ML, Conley EC, Bradding P (2001b) Voltagedependent and calcium-activated ion channels in the human mast cell line HMC-1. J Leukoc Biol 70:233-240

Duffy SM, Lawley WJ, Kaur D, Yang W, Bradding P (2003) Inhibition of human mast cell proliferation and survival by tamoxifen in association with ion channel modulation. J Allergy Clin Immunol 112:965-972

Friis UG, Johansen T, Hayes NA, Foreman JC (1994) IgE-receptor activated chloride uptake in relation to histamine secretion from rat mast cells. Br J Pharmacol 111:1179-1183

Guharay F, Sachs F (1984) Stretch-activated single ion channel currents in tissue-cultured embryonic chick skeletal muscle. J Physiol 352:685-701

Hamill OP, Martinac B (2001) Molecular basis of mechanotransduction in living cells. Physiol Rev 81:685-740

Hamill OP, McBride DW Jr (1992) Rapid adaptation of single mechanosensitive channels in Xenopus oocytes. Proc Natl Acad Sci USA 89:7462-7466

Hill PB, Martin RJ, Miller HR (1996) Characterization of whole-cell currents in mucosal and connective tissue rat mast cells using amphotericin-B-perforated patches and temperature control. Pflugers Arch 432:986-994

Jensen TB, Friis UG, Johansen T (1998) Role of physiological $\mathrm{HCO}_{3}{ }^{-}$buffer on intracellular $\mathrm{pH}$ and histamine release in rat peritoneal mast cells. Pflugers Arch 436:357-364

Jentsch TJ, Stein V, Weinreich F, Zdebik AA (2002) Molecular structure and physiological function of chloride channels. Physiol Rev 82:503-568

Kulka M, Gilchrist M, Duszyk M, Befus AD (2002) Expression and functional characterization of CFTR in mast cells. J Leukoc Biol 71:54-64

Kuno M, Shibata T, Kawawaki J, Kyogoku I (1995) A heterogeneous electrophysiological profile of bone marrow-derived mast cells. J Membr Biol 143:115-122

Lewis RS, Ross PE, Cahalan MD (1993) Chloride channels activated by osmotic stress in T lymphocytes. J Gen Physiol 101:801-826
Matsuda JJ, Filali MS, Volk KA, Collins MM, Moreland JG, Lamb FS (2008) Overexpression of CLC-3 in HEK293T cells yields novel currents that are $\mathrm{pH}$ dependent. Am J Physiol Cell Physiol 294:C251-262

Matthews G, Neher E, Penner R (1989) Chloride conductance activated by external agonists and internal messengers in rat peritoneal mast cells. J Physiol 418:131-144

Meyer G, Doppierio S, Vallin P, Daffonchio L (1996) Effect of frusemide on $\mathrm{Cl}^{-}$channel in rat peritoneal mast cells. Eur Respir J 9:2461-2467

Miller C (2006) ClC chloride channels viewed through a transporter lens. Nature 440:484-489

Miller C, White MM (1984) Dimeric structure of single chloride channels from Torpedo electroplax. Proc Natl Acad Sci USA 81:2772-2775

Monaghan AS, Mintenig GM, Sepulveda FV (1997) Outwardly rectifying $\mathrm{Cl}^{-}$channel in guinea pig small intestinal villus enterocytes: effect of inhibitors. Am J Physiol 273:G1141-1152

Monck JR, Alvarez de Toledo G, Fernandez JM (1990) Tension in secretory granule membranes causes extensive membrane transfer through the exocytotic fusion pore. Proc Natl Acad Sci USA 87:7804-7808

Neher E (1988) The influence of intracellular calcium concentration on degranulation of dialysed mast cells from rat peritoneum. J Physiol 395:193-214

Nilius B, Eggermont J, Voets T, Droogmans G (1996) Volumeactivated $\mathrm{Cl}^{-}$channels. Gen Pharmacol 27:1131-1140

Nishida K, Yamasaki S, Ito Y, Kabu K, Hattori K, Tezuka T, Nishizumi H, Kitamura D, Goitsuka R, Geha RS, Yamamoto T, Yagi T, Hirano T (2005) Fc epsilon\}RI-mediated mast cell degranulation requires calcium-independent microtubule-dependent translocation of granules to the plasma membrane. J Cell Biol 170:115-126

Noli C, Miolo A (2001) The mast cell in wound healing. Vet Dermatol 12:303-313

Ordway RW, Singer JJ, Walsh JV Jr (1991) Direct regulation of ion channels by fatty acids. Trends Neurosci 14:96-100

Patel AJ, Lauritzen I, Lazdunski M, Honore E (1998) Disruption of mitochondrial respiration inhibits volume-regulated anion channels and provokes neuronal cell swelling. J Neurosci 18:31173123

Penner R, Matthews G, Neher E (1988) Regulation of calcium influx by second messengers in rat mast cells. Nature 334:499-504

Poolman B, Blount P, Folgering JH, Friesen RH, Moe PC, van der Heide T (2002) How do membrane proteins sense water stress? Mol Microbiol 44:889-902

Pusch M, Zifarelli G, Murgia AR, Picollo A, Babini E (2006) Channel or transporter? The CLC saga continues. Exp Physiol 91:149152

Rohlich P, Anderson P, Uvnas B (1971) Electron microscope observations on compounds 48-80-induced degranulation in rat mast cells. Evidence for sequential exocytosis of storage granules. J Cell Biol 51:465-483

Roloff T, Wordehoff N, Ziegler A, Seebeck J (2001) Evidence against the functional involvement of outwardly rectifying $\mathrm{Cl}^{-}$channels in agonist-induced mast cell exocytosis. Eur J Pharmacol 431:19

Romanin C, Reinsprecht M, Pecht I, Schindler H (1991) Immunologically activated chloride channels involved in degranulation of rat mucosal mast cells. EMBO J 10:3603-3608

Sabirov RZ, Dutta AK, Okada Y (2001) Volume-dependent ATPconductive large-conductance anion channel as a pathway for swelling-induced ATP release. J Gen Physiol 118:251-266

Sackin H (1995) Mechanosensitive channels. Annu Rev Physiol $57: 333-353$ 
Sato R, Koumi S (1998) Characterization of the stretch-activated chloride channel in isolated human atrial myocytes. J Membr Biol 163:67-76

Scheel O, Zdebik AA, Lourdel S, Jentsch TJ (2005) Voltagedependent electrogenic chloride/proton exchange by endosomal CLC proteins. Nature 436:424-427

Schwiebert EM, Mills JW, Stanton BA (1994) Actin-based cytoskeleton regulates a chloride channel and cell volume in a renal cortical collecting duct cell line. J Biol Chem 269:7081-7089

Wang LN, Wolfgang S, Gu QB, Ding GH (2009) Skin slice as a model for the investigation of acupuncture effects (in Chinese). Zhen Ci Yan Jiu (Acupunct Res Chin) 34:291-296

Watanabe Y, Todome Y, Ohkuni H, Sakurada S, Ishikawa T, Yutsudo T, Fischetti VA, Zabriskie JB (2002) Cysteine protease activity and histamine release from the human mast cell line HMC-1 stimulated by recombinant streptococcal pyrogenic exotoxin $\mathrm{B} / \mathrm{streptococcal}$ cysteine protease. Infect Immun 70:3944-3947

Wu J, Zhang JJ, Koppel H, Jacob TJ (1996) P-glycoprotein regulates a volume-activated chloride current in bovine non-pigmented ciliary epithelial cells. J Physiol 491:743-755

Yong LC (1997) The mast cell: origin, morphology, distribution, and function. Exp Toxicol Pathol 49:409-424

Zhang D, Ding G, Shen X, Yao W, Zhang Z, Zhang Y, Lin J, Gu Q (2008) Role of mast cells in acupuncture effect: a pilot study. Explore (NY) 4:170-177 